\title{
Effect of feeding maternal colostrum or plasma-derived or colostrum-derived colostrum replacer on passive transfer of immunity, health, and performance of preweaning heifer calves
}

\author{
D. Priestley, ${ }^{*}$ J. H. Bittar, ${ }^{*}$ L. Ibarbia, ${ }^{*}$ C. A. Risco, ${ }^{*}$ and K. N. Galvão*$\dagger^{1}$ \\ *Department of Large Animal Clinical Sciences, and \\ †D. H. Barron Reproductive and Perinatal Biology Research Program, University of Florida, Gainesville 32610
}

\section{ABSTRACT}

The objective of this study was to evaluate the effect of feeding maternal colostrum (MC), a plasma-derived (PDCR) or colostrum-derived colostrum replacer (CDCR) on passive transfer of immunity, health, and performance of preweaning heifer calves. Preplanned contrasts were performed for $\mathrm{MC}$ versus $\mathrm{CR}$ (PDCR combined with CDCR) and PDCR versus CDCR. At birth, calves were randomly assigned to 1 of 3 treatment groups: $\mathrm{MC}(\mathrm{n}=49), 3.8 \mathrm{~L}$ of maternal colostrum; PDCR ( $\mathrm{n}=49), 550 \mathrm{~g}$ (1 dose; $150 \mathrm{~g}$ of $\mathrm{IgG}$ ) of a PDCR; or CDCR ( $\mathrm{n}=49), 470 \mathrm{~g}$ (1 dose; $100 \mathrm{~g}$ $\mathrm{IgG}$ ) of a CDCR. The best total protein cutoff for determining passive transfer was $>5.2,5.6$, and $5.1 \mathrm{~g} / \mathrm{dL}$ for MC, PDCR, and CDCR, respectively. Serum total protein was greater for calves fed $\mathrm{MC}$ (mean $\pm \mathrm{SE}$; $6.14 \pm 0.11 \mathrm{~g} / \mathrm{dL}$ ) than for calves fed PDCR (5.29 \pm $0.11 \mathrm{~g} / \mathrm{dL})$ and CDCR $(5.27 \pm 0.11 \mathrm{~g} / \mathrm{dL})$. Serum $\operatorname{IgG}$ concentrations were greater for calves fed MC $(2,098$ $\pm 108 \mathrm{~g} / \mathrm{dL})$ than for calves fed PDCR $(927 \pm 107 \mathrm{~g} /$ $\mathrm{dL})$ or CDCR $(1,139 \pm 108 \mathrm{~g} / \mathrm{dL})$. Apparent efficiency of absorption was greater for CDCR than PDCR (38.8 \pm 3.0 vs. $21.6 \pm 3.0 \%)$. Adequate passive transfer was greatest for MC (91.8\%), followed by CDCR (49\%) and PDCR (28.6\%). Calves fed MC had greater weaning weights and body weight gain than calves fed CR. Morbidity was lower for calves fed MC (46.9\%) than for calves fed PDCR (71.4\%) or CDCR (67.3\%). Calves fed MC tended to have lower mortality than calves fed CR. Given the conditions of this trial, feeding $3.8 \mathrm{~L}$ of $\mathrm{MC}$ was superior to feeding one dose of CR. Further research is needed to evaluate calf performance when a higher dose of CR is fed.

Key words: maternal colostrum, colostrum replacer, performance, dairy calf

Received November 2, 2012.

Accepted January 9, 2013.

${ }^{1}$ Corresponding author: galvaok@ufl.edu

\section{INTRODUCTION}

Colostrum management and feeding is critical for calf health, their future productive life, and farm profitability (Robison et al., 1988; Faber et al., 2005). It is currently recommended that a calf needs to ingest at least 150 to $200 \mathrm{~g}$ of $\operatorname{IgG}$ within $2 \mathrm{~h}$ of birth to achieve successful passive transfer (Chigerwe et al., 2008b). It is understood that this can be reached by feeding 3 to $4 \mathrm{~L}$ of good quality maternal colostrum (MC); namely, an MC with IgG concentration greater than $50 \mathrm{~g} / \mathrm{L}$, bacterial count less than 100,000 $\mathrm{cfu} / \mathrm{mL}$, and coliform count less than 10,000 cfu/mL (McGuirk and Collins, 2004; Chigerwe et al., 2008b). A hydrometer (colostrometer) can be used as an on-farm test for guidance on colostrum quality; colostrum contains at least $50 \mathrm{~g} / \mathrm{L}$ of $\mathrm{IgG}$ when the colostrometer reads $70 \mathrm{~g} / \mathrm{L}$ or more (Chigerwe et al., 2008a).

However, when colostrum quality is poor or unavailable, colostrum replacer (CR) may be a suitable alternative to $\mathrm{MC}$ because it is easier to store and process. Advantages over MC may also exist when considering bacterial contamination, and recent studies have found that feeding a CR can reduce the transmission of Johne's disease by $44 \%$ (Pithua et al., 2009). Varying reports have been published on the success of passive transfer when CR is used. Poulsen et al. (2010) found no significant difference in rates of passive transfer between a bovine serum-based CR and maternal colostrums. Conversely, Swan et al. (2007) found higher rates of failure of passive transfer when a CR was fed, which could impair health and survival. Fidler et al. (2011) and Godden et al. (2009a) found similar results when calves were fed a commercial $\mathrm{CR}$ at the recommended dose. Despite higher rates of failure of passive transfer, a recent report found no difference in mortality rates from birth to first calving (Pithua et al., 2010). Nonetheless, others have observed that mortality was twice as high for heifers with failure of passive transfer compared with heifers with successful transfer (Robison et al., 1988; Wells et al., 1996). More information on morbidity and mortality of calves fed 
CR would improve the body of knowledge and help the producer make an informed decision about colostrum feeding management.

It is widely accepted that a serum total protein $(\mathbf{T P})$ of at least 5.2 to $5.5 \mathrm{~g} / \mathrm{dL}$ correlates well with calves achieving successful passive transfer (Weaver et al., 2000); that is, reaching serum IgG concentrations of $1,000 \mathrm{mg} / \mathrm{dL}$ (the gold standard test). However, some commercial products (e.g., Acquire Colostrum Replacer; APC Inc., Ankeny, IA) indicate that when feeding their product, (plasma-derived CR), a serum TP cutoff of $4.7 \mathrm{~g} / \mathrm{dL}$ would be more appropriate. A cutoff of $4.2 \mathrm{~g} /$ dL (Quigley et al., 2002) or $4.85 \mathrm{~g} / \mathrm{dL}$ (Mowrey, 2001) has been suggested as appropriate cutoffs for determining passive transfer when using a plasma-derived CR (PDCR). It has been suggested that a bovine PDCR may allow superior absorption compared with a lactealderived CR (Quigley et al., 2001); however, this has not been substantiated by recent preliminary reports (Place et al., 2010).

Therefore, the objective of this study was to evaluate the effect of feeding MC, 1 dose of PDCR, or 1 dose of colostrum-derived CR (CDCR) on serum TP, IgG concentration, calf morbidity (disease incidence), calf mortality, and weight gain from birth to weaning. Preplanned contrasts were performed for MC versus CR (PDCR combined with CDCR) and PDCR versus CDCR. A secondary objective was to determine the cutoff value for TP for prediction of passive immunity and the apparent efficiency of absorption (AEA) of IgG when feeding PDCR or CDCR.

\section{MATERIALS AND METHODS}

\section{Animals, Housing, Feeding, and Vaccination Program}

One hundred and fifty Holstein heifer calves were enrolled into the study at birth, between October and December 2011, from a commercial dairy farm milking 3,000 cows, located in Bell County, Florida. The observation period was completed at the end of January 2012. A sample size of 150 calves (50 per treatment group) was calculated (Minitab Inc., State College, PA) for $\alpha=0.05$ and $\beta=0.2$, to detect differences in weaning weight of $5 \mathrm{~kg}$ (SD of $8 \mathrm{~kg}$ ) and death losses of $10 \%$. Bull calves, twins, and crossbred animals were excluded from enrollment. Prepartum cows were monitored hourly, and calves were removed from their dam immediately after calving to prevent suckling.

Calves were housed from birth to weaning in individual, covered hutches placed on top of sand $1.5 \mathrm{~m}$ apart from each other. Aside from treatment at birth (MC or CR), calves were fed 3.0 L of milk twice daily from $\mathrm{d} 1$ to $49 \pm 3$, then received $3.0 \mathrm{~L}$ of milk in the morning from d $50 \pm 3$ to $56 \pm 3$, and were weaned from milk at d $56 \pm 3 \mathrm{~d}$. All milk was derived from the farm's hospital herd and pasteurized before being fed to the calves. Calves were offered starter grain and water ad libitum from d 1 to $56 \pm 3 \mathrm{~d}$.

\section{Treatments}

At birth calves were randomly assigned, following an excel-generated random list, to one of 3 treatment groups: $\mathrm{MC}=3.8 \mathrm{~L}$ of maternal colostrum; PDCR $=$ $550 \mathrm{~g}$ of Acquire CR containing $150 \mathrm{~g}$ (1 dose) of IgG (APC Inc.) dissolved in warm water to make $3.8 \mathrm{~L}$ of solution; CDCR $=470 \mathrm{~g}$ of Calf's Choice Total Silver (Balanced) CR containing $100 \mathrm{~g}$ (1 dose) of IgG (Alta Genetics USA Inc., Watertown, WI) dissolved in warm water to make $3.8 \mathrm{~L}$ of solution. The recommendation for PDCR and CDCR is to dissolve one dose in 1.4 and $1.25 \mathrm{~L}$ of water, respectively; however, a decision was made to standardize the volume of solution fed to all calves to eliminate volume fed as a confounder (Jones et al., 2004) and because mass of IgG fed is more important than concentration (Stott and Fellah, 1983). These CR products are licensed as an aid in the prevention of failure of passive transfer and are regulated by the USDA. Testing by the National Veterinary Services Laboratory (Ames, IA) ensures that products meet the requirements for sale, including microbiologic safety and concentration of IgG per dose advertised. All calves were fed via an esophageal tube within $2 \mathrm{~h}$ of birth.

Colostrum was harvested aseptically after predipping, wiping, and drying the teats, using a vacuum milking system in a herringbone milking parlor. All maternal colostrum was tested by a colostrometer and only colostrum measuring at least $70 \mathrm{~g} / \mathrm{L}$ of $\mathrm{IgG}$ was fed to the calves; therefore, we estimate that a minimum of $190 \mathrm{~g}$ of $\operatorname{IgG}(3.8 \mathrm{~L} \times 50 \mathrm{~g}$ of $\mathrm{IgG} / \mathrm{L})$ was fed to MC calves (Chigerwe et al., 2008a). Fresh harvested colostrum was immediately fed to newborn calves, and excess was stored in $3.8 \mathrm{~L}$ bags and frozen at $-20^{\circ} \mathrm{C}$. Calves were usually fed fresh colostrum; however, if sufficient good quality fresh colostrum was not available, a 3.8-L bag was thawed and fed. Samples of MC were collected before feeding for aerobic culture at a commercial laboratory (All Florida Veterinary Laboratory Inc., Archer, FL). All samples had counts below 20,000 $\mathrm{cfu} / \mathrm{mL}$, with the exception of one that was 500,000 $\mathrm{cfu} / \mathrm{mL}$.

\section{BW Measurement and Blood Sample Collection and Analyses}

All calves had their BW recoded at birth and at weaning or $1 \mathrm{~d}$ before weaning $(55 \pm 4 \mathrm{~d})$ using an 
electronic scale (model 701and MP600 multi-purpose load bars, Tru-Test Ltd., Pakuranga Manukau, New Zealand).

A blood sample $(8 \mathrm{~mL})$ was collected from every calf at $\mathrm{d} 1$ to 7 of age $($ mean $=4.3 \mathrm{~d}), 30 \mathrm{~min}$ before the morning feeding by puncture of the jugular vein into evacuated tubes with no anti-coagulant (Vacutainer; Becton Dickinson, Franklin Lakes, NJ). Samples were allowed to clot and then placed on ice and tubes were centrifuged at $3000 \times g$ for $10 \mathrm{~min}$ at room temperature for serum separation. After calibration, a refractometer was then used to read serum TP. Remaining serum was then frozen at $-25^{\circ} \mathrm{C}$ and later analyzed for $\mathrm{IgG}$ concentration using a radial immunodiffusion test kit (Triple J Farms, Bellingham, WA) according to the manufacturer's protocol. Briefly, $5 \mu \mathrm{L}$ of serum sample was added to the wells in the gel containing anti-bovine IgG antibody and incubated for $27 \mathrm{~h}$ at room temperature in the absence of light exposure. After incubation, the diameter of the precipitation rings was measured and total IgG concentration was calculated based on the linear relationship between diameters squared and total IgG concentration. The interassay $\mathrm{CV}$ of the radial immunodiffusion assay was $4.3 \%$. This test was considered the gold standard for identifying calves with failure of passive transfer; calves with a serum $\operatorname{IgG}$ concentration less than $1,000 \mathrm{mg} / \mathrm{dL}$ were considered to have failure of passive transfer (Dawes et al., 2002). The AEA of IgG was calculated for the PDCR and CDCR groups using the following formula as previously reported (Quigley and Drewry, 1998; Godden et al., 2009a):

$$
\begin{gathered}
\mathrm{AEA}=\{(\text { Serum }[\mathrm{IgG}], \mathrm{g} / \mathrm{L} \times \text { Birth weight } \\
\mathrm{kg} \times 0.09) / \mathrm{IgG} \text { intake }, \mathrm{g}\} \times 100 .
\end{gathered}
$$

Serum volume was considered as $9 \%$ of the birth weight as previously reported (Tao et al., 2012).

\section{Health Scoring, Health Events, and Death Events}

Disease incidence and death loss, along with cause of death, was recorded weekly by the same investigator, who was blind to treatments. Health events were evaluated using a chart (Table 1) adapted from the School of Veterinary Medicine, University of Wisconsin-Madison calf health scoring chart (found at: http://www.vetmed.wisc.edu/dms/fapm/fapmtools/8calf/calf_health_ scoring_chart.pdf). Calves were diagnosed with either pneumonia or diarrhea when they had a total respiratory score (combined cough, highest ear or eye score, and nasal discharge score) of at least 4 or a fecal score of at least 2 , respectively. Besides weekly scoring, calves were also monitored daily by trained farm personnel that used the same chart to record symptoms of any calf receiving treatment. Those records were combined with the weekly evaluations and used in the statistical analysis pertaining to disease events. Dairy personnel diagnosing disease and performing treatments were also blind to colostrum treatment. Once diagnosed, calves were treated using normal farm protocols. For pneumonia, this included florfenicol (Nuflor; Merck Animal Health Inc., Summit, NJ) and flunixin meglumine (Banamine; Merck Animal Health) if the calf's temperature was above $104^{\circ} \mathrm{C}$. Diarrhea was initially treated with oral fluids and gut protectant (Kaolin-Pectin 4; Vet One; http://www.vetone.net/default.html), followed by sulfamethiazine (Albon; Pfizer Animal Health Inc. New York, NY) if no improvement was observed after $2 \mathrm{~d}$. Other than diarrhea and pneumonia, calves were also treated for septic arthritis and omphalitis using ceftiofur hydrochloride (Excenel; Pfizer Animal Health).

At 3 and 5 wk calves received a modified live vaccine containing bovine rhinotracheitis virus, bovine viral diarrhea virus types 1 and 2, bovine parainfluenza- 3 virus, and bovine respiratory syncytial virus (Bovishield Gold 5; Pfizer Animal Health). At 5 and 7 wk, calves received an 8-way Clostridium vaccine (Ultrabac 8; Pfizer Animal Health).

\section{Statistical Analyses}

Of the 150 calves enrolled, only 147 (49 in each treatment) were used for statistical analysis. One calf was enrolled but died the same day, and one calf received 2 types of colostrum on the same day (i.e., enrolled twice), therefore 3 records were removed. Only 123 calves were used in the weight gain analysis because 24 calves died during the trial, leaving 37,41 , and 45 calves in the CDCR, PDCR, and MC groups, respectively.

The best serum TP cutoff for predicting an IgG concentration, $>1,000 \mathrm{mg} / \mathrm{dL}$, was performed by receiver operating characteristic (ROC) curve analysis using MedCalc version 9.2 (MedCalc Software, Mariakerke, Belgium). The ROC curve analysis plots the sensitivity (Se) against the false-positive fraction (1 - specificity; Sp) to detect the best combination of Se and Sp for all TP values (Zweig and Campbell, 1993; Bicalho et al., 2008).

Continuous data, such as birth weight, serum TP concentration, IgG concentration, AEA, weight gain, and weaning weight, were analyzed by the GLM procedure of SAS (SAS Institute Inc., Cary, NC), and least squares means \pm standard error of the mean are presented. The models included the main effects of treatment, birth weight, and interaction between treatment 
Table 1. Calf health scoring chart ${ }^{1}$

\begin{tabular}{|c|c|c|c|c|}
\hline Clinical sign & \multicolumn{4}{|c|}{ Score } \\
\hline Nasal discharge & Normal serous discharge & $\begin{array}{l}\text { Small amount of unilateral } \\
\text { cloudy discharge }\end{array}$ & $\begin{array}{l}\text { Bilateral, cloudy, or excessive } \\
\text { mucus discharge }\end{array}$ & $\begin{array}{l}\text { Copious bilateral } \\
\text { mucopurulent discharge }\end{array}$ \\
\hline Eye scores $^{2}$ & Normal & $\begin{array}{l}\text { Small amount of ocular } \\
\text { discharge }\end{array}$ & $\begin{array}{l}\text { Moderate amount of bilateral } \\
\text { discharge }\end{array}$ & Heavy ocular discharge \\
\hline Fecal scores & Normal & Semi-formed, pasty & $\begin{array}{l}\text { Loose, but stays on top of } \\
\text { bedding }\end{array}$ & Watery, sifts through bedding \\
\hline
\end{tabular}

\footnotetext{
${ }^{1}$ Adapted from the University of Wisconsin-Madison calf health scoring chart that can be found at http://www.vetmed.wisc.edu/dms/fapm/ fapmtools/8calf/calf_health_scoring_chart.pdf.

${ }^{2}$ Highest score of either parameter recorded, but not both. This was then added to the cough and nasal discharge scores to make the total respiratory score.
}

and birth weight. Effect of morbidity on weaning weight and weight gain was analyzed univariately using the GLM procedure of SAS. Morbidity was not included as an independent variable in the models for weaning weight and weight gain because treatment had an effect on morbidity; therefore, morbidity would become an intermediate variable (Hull, 1980). Multiple comparisons were performed when an effect of treatment was observed using the Dunnett adjustment option.

Binary data, such as adequate passive transfer (yes or no), morbidity $($ any disease $=$ yes; no disease $=$ no $)$, and mortality (died = yes; alive = no), were analyzed using the LOGISTIC procedure of SAS using a model similar to GLM. Effect of passive transfer of immunity on morbidity and mortality was analyzed univariately using the LOGISTIC procedure of SAS. Passive transfer was not included as an independent variable in the models for morbidity and mortality because treatment had an effect on passive transfer; therefore, passive transfer would become an intermediate variable (Hull, 1980).

Time to the first disease event or death was analyzed using the LIFETEST procedure of SAS, and survival curves were built using MedCalc version $9.2 ; P$-values for the log-rank test were presented. For both the GLM and LOGISTIC models, treatment was forced in the final models but other variables were removed if $P>0.10$ based on Wald statistics criterion. In a multivariable model, the LSM (GLM) or odds ratio (LOGISTIC) are adjusted for all variables left in the model. Preplanned contrasts were performed for $\mathrm{MC}$ versus $\mathrm{CR}$ (PDCR combined with CDCR) and PDCR versus CDCR. Differences with $P \leq 0.05$ were considered significant, and $0.05<P \leq 0.10$ was considered a tendency toward statistical difference.

\section{RESULTS}

\section{TP, IgG Concentration, AEA, and Passive Transfer}

The ROC curve analysis showed that the best serum TP cutoff for predicting an IgG concentration of 1,000 $\mathrm{mg} / \mathrm{dL}$ was $>5.2 \mathrm{~g} / \mathrm{dL}[\mathrm{Se}=84.4, \mathrm{Sp}=100$, area under the curve $($ AUC $)=0.94 ; P<0.001]$ for $\mathrm{MC},>5.6 \mathrm{~g} /$ $\mathrm{dL}(\mathrm{Se}=63.2, \mathrm{Sp}=94.3, \mathrm{AUC}=0.78 ; P=0.002)$ for $\mathrm{PDCR}$, and $>5.1 \mathrm{~g} / \mathrm{dL}(\mathrm{Se}=79.2, \mathrm{Sp}=72.0, \mathrm{AUC}=$ $0.83 ; P<0.001)$ for CDCR.

Treatment significantly $(P<0.001)$ affected serum TP (Table 2). Multiple comparisons showed that serum TP were greater $(P<0.001)$ for calves fed MC $(6.1 \pm$ $0.11 \mathrm{~g} / \mathrm{dL})$ than for calves fed PDCR $(5.3 \pm 0.11 \mathrm{~g} / \mathrm{dL})$ or CDCR $(5.3 \pm 0.11 \mathrm{~g} / \mathrm{dL})$. No difference $(P=0.89)$ was observed between the PDCR and CDCR groups. Treatment significantly $(P<0.001)$ affected serum IgG concentration (Table 2). Serum IgG concentrations were greater $(P<0.0001)$ for calves fed MC $(2,098 \pm$ $108 \mathrm{~g} / \mathrm{dL})$ than for calves fed PDCR $(927 \pm 107 \mathrm{~g} / \mathrm{dL})$ or CDCR $(1139 \pm 108 \mathrm{~g} / \mathrm{dL})$. No difference $(P=0.16)$ was observed between the PDCR and CDCR groups.

Treatment affected $(P<0.001)$ AEA, and CDCR had greater AEA than PDCR $(38.8 \pm 3.0$ vs. $21.6 \pm$ $3.0 \%)$. Apparent efficiency of absorption could not be calculated or reported for the MC group because the dose of IgG fed to these calves was not quantified. Birth weight also affected $(P=0.01)$ AEA, and the relationship was positive $(\mathrm{AEA}=-13.19+1.15 \times$ Birth weight). No interaction was observed between treatment and birth weight $(P=0.51)$ on AEA.

Treatment also affected $(P<0.001)$ the proportion of calves with adequate passive transfer, with all treatment groups being significantly $(P<0.05)$ different $(\mathrm{MC}=91.8, \mathrm{PDCR}=28.6$, and $\mathrm{CDCR}=49.0 \%)$. 
Table 2. Effect of treatment with different types of colostrum on preweaning calf health and growth

\begin{tabular}{|c|c|c|c|c|c|c|c|c|}
\hline Item & \multicolumn{3}{|c|}{ Treatment $^{1}$} & SEM & $\begin{array}{c}\mathrm{CR}^{2} \\
\mathrm{n}=98\end{array}$ & \multicolumn{3}{|c|}{$P$-value ${ }^{3}$} \\
\hline $\begin{array}{l}{ }^{\mathrm{a}-\mathrm{C}} \text { Values within a row are } \\
\mathrm{A}, \mathrm{B} \text { Values within a row tend } \\
{ }^{1} \mathrm{MC}=\text { calves that within } 2 \\
\text { derived colostrum replacer } \\
\text { tion; CDCR = calves that } \\
\text { Genetics USA Inc., Watert } \\
{ }^{2} \mathrm{CR}=\text { values for PDCR co } \\
{ }^{3} \mathrm{TRT}=\text { treatment; } \mathrm{C} 1=\mathrm{c} \\
{ }^{4} \mathrm{AEA}=\text { apparent efficiency } \\
{ }^{5} \text { Passive transfer defined by }\end{array}$ & $\begin{array}{l}\text { cantly differ } \\
\text { ffer, } P \leq 0 \text {. } \\
\text { birth were } \\
\text { dire Colostr } \\
2 \text { h of birt } \\
\text { WI) contain } \\
\text { d with CD } \\
\text { t between } \\
\text { sorption. }\end{array}$ & $\begin{array}{l}P<0.05 \\
3.8 \mathrm{~L} \text { of } \mathrm{m} \\
\text { Replacer, } \\
\text { ere fed } 47 \\
100 \mathrm{~g} \text { of } \mathrm{I} \\
\text { and } \mathrm{CR}\end{array}$ & $\begin{array}{l}\text { nal colostr } \\
\text { keny, IA) c } \\
\text { ff colostrur } \\
\text { ssolved in } \\
\text { R combin }\end{array}$ & $\begin{array}{l}\text { PDCR } \\
\text { aining } 1 \\
\text { rived c } \\
\text { n water } \\
\text { rith CD }\end{array}$ & $\begin{array}{l}\text { alves that wit } \\
\mathrm{g} \text { of } \mathrm{Ig} \text { dissolv } \\
\text { trum replacer } \\
\text { make } 3.8 \mathrm{~L} \text { of } \\
\text { ); } \mathrm{C} 2=\text { contra }\end{array}$ & $\begin{array}{l}\text { h of birt } \\
\text { warm w } \\
\text { Calf's C } \\
\text { ion. } \\
\text { tween PI }\end{array}$ & $\begin{array}{l}\text { re fed } 5 \\
\text { to make } \\
\text { e Total } \\
\text { and CD }\end{array}$ & $\begin{array}{l}\text { of plasma- } \\
\text { L of solu- } \\
\text { nced; Alta }\end{array}$ \\
\hline
\end{tabular}

Adequate passive transfer was greatest for MC (91.8\%) followed by CDCR (49\%) and PDCR (28.6\%). Birth weight or interaction between treatment and birth weight did not affect any other variable besides AEA $(P>0.15)$.

\section{Birth Weight, Weaning Weight, and Weight Gain}

A tendency $(P=0.07)$ was observed for an association between treatment and birth weight (Table 2). Calves fed MC were lighter $(P=0.02)$ at birth than calves fed CDCR $(35.9 \pm 0.8$ vs. $38.4 \pm 0.8 \mathrm{~kg})$, but no difference $(P>0.20)$ existed between MC and PDCR $(37.0 \pm 0.8 \mathrm{~kg})$ calves or PDCR and CDCR calves. Contrast showed that calves fed MC were lighter $(P=$ $0.05)$ at birth than calves receiving CR $(37.7 \pm 0.6 \mathrm{~kg})$. Morbidity significantly $(P<0.001)$ affected weaning weight and BW gain from birth to weaning; calves that had at least one disease event $(\mathrm{n}=91)$ had decreased weaning weight $(57.5 \pm 0.7$ vs. $61.7 \pm 0.8 \mathrm{~kg})$ and $\mathrm{BW}$ gain from birth to weaning $(20.5 \pm 0.8$ vs. $25.5 \pm 0.8$ $\mathrm{kg})$ compared with calves that remained healthy $(\mathrm{n}=$ $56)$.

Treatment significantly $(P=0.008)$ affected weaning weight (Table 2). Weaning weights were greater $(P=$ $0.002)$ for calves fed MC $(61.2 \pm 0.9 \mathrm{~kg})$ than calves fed PDCR $(57.2 \pm 0.9 \mathrm{~kg})$, but similar $(P=0.19)$ to calves fed CDCR $(59.5 \pm 0.9 \mathrm{~kg})$. Weaning weights tended $(P$ $=0.08)$ to be greater for calves fed CDCR than calves fed PDCR. Contrasts showed that calves fed MC had greater $(P=0.01)$ weaning weights than calves fed $\mathrm{CR}$ $(58.4 \pm 0.7 \mathrm{~kg})$. Birth weight also affected $(P<0.001)$ weaning weights, and the relationship was positive (weaning weight $=43.9+0.425 \times$ birth weight). No interaction was observed between treatment and birth weight $(P=0.35)$ on weaning weight.

Treatment significantly $(P=0.007)$ affected BW gain from birth to weaning (Table 2). Weight gains were greater $(P=0.002)$ for calves fed MC $(24.6 \pm 0.9 \mathrm{~kg})$ than calves fed PDCR $(20.7 \pm 0.9 \mathrm{~kg})$, but similar $(P=$ $0.17)$ to calves fed CDCR $(22.9 \pm 0.9 \mathrm{~kg})$. Weight gains tended $(P=0.09)$ to be greater for calves fed CDCR than calves fed PDCR. Contrasts showed that calves fed MC had greater $(P=0.009) \mathrm{BW}$ gains than calves fed CR $(21.8 \pm 0.6 \mathrm{~kg})$. Birth weight also affected $(P$ $<0.001$ ) weight gain, and the relationship was negative (weight gain $=43.9-0.5751 \times$ birth weight). No interaction was observed between treatment and birth weight $(P=0.33)$ on weaning weight.

\section{Morbidity and Mortality}

Calves with failure of passive transfer had increased $(P<0.03)$ morbidity $[71.9(46 / 64)$ vs. $54.2 \%(45 / 83)]$ and mortality $[25.0(16 / 64)$ vs. $9.6 \%(8 / 83)]$ as compared with calves without failure of passive transfer. Treatment significantly $(P=0.03)$ affected morbidity (Table 3). Morbidity was lower $(P \leq 0.04)$ for calves fed MC $(46.9 \%)$ than for calves fed PDCR $(71.4 \%)$ or CDCR $(67.3 \%)$. Morbidity was similar $(P=0.66)$ between calves fed PDCR and CDCR; contrasts showed that calves fed MC had lower $(P=0.009)$ morbidity than calves fed CR (69.4\%). When looking at each disease separately, treatment tended $(P=0.09)$ to af- 
fect the incidence of diarrhea. Calves fed PDCR had greater $(P=0.04)$ incidence of diarrhea $(49.0 \%)$ than calves fed MC $(28.6 \%)$, and calves fed CDCR tended $(P$ $=0.10)$ to have greater incidence $(44.9 \%)$ of diarrhea than calves fed MC. Contrast showed that incidence of diarrhea was greater $(P=0.03)$ in calves fed $\mathrm{CR}$ $(46.9 \%)$ than in calves fed MC, but similar $(P=0.69)$ between PDCR and CDCR. Treatment had no effect $(P>0.30)$ on incidence or pneumonia or other diseases (arthritis plus omphalitis). Incidence of pneumonia for MC, PDCR, and CDCR was 24.5, 38.8, and 32.7.0\%, respectively. Incidence of other diseases for MC, PDCR, and CDCR was 4.1, 2.0, and 6.1\%, respectively.

Treatment tended $(P=0.09)$ to affect mortality (Table 3$)$. Mortality was lower $(P=0.03)$ for calves fed MC $(8.2 \%)$ than for calves fed CDCR $(24.5 \%)$; however, mortality was similar $(P \geq 0.22)$ between calves fed MC and PDCR (16.3\%) and between PDCR and CDCR. Contrasts showed that calves fed MC tended $(P=0.06)$ to have lower mortality than calves fed CR $(20.4 \%)$.

Treatment significantly $(P=0.009)$ affected time to first disease event (Figure 1). Time to first disease event was increased $(P<0.02)$ for calves fed MC compared with PDCR and CDCR. Contrasts showed that MC had an increased time to first disease event $(P=$ 0.003) compared with CR, but PDCR was not different than CDCR $(P=0.54)$. Median time to first disease event was 58, 18, and $20 \mathrm{~d}$ for MC, PDCR, and CDCR, respectively. Proportion of healthy calves at the end of the study were $53.1(26 / 49), 28.6(14 / 49)$, and $32.7 \%$ (16/49), for MC, PDCR, and CDCR, respectively.
Time to death is shown in Figure 2; a tendency $(P=0.10)$ for an effect of treatment was observed. Calves fed MC treatment had an increased $(P=0.03)$ time to death compared with CDCR, but similar $(P$ $=0.20)$ to PDCR. Contrasts showed that calves fed MC had a tendency for decreased time to death $(P=$ 0.06) compared with CR, but PDCR was not different than CDCR $(P=0.39)$. Median time to death was not calculated because more than $50 \%$ of the calves were alive at the end of the study. Proportion of live calves were 91.8 (45/49), $83.7(41 / 49)$, and $75.5 \%$ (37/49), for $\mathrm{MC}, \mathrm{PDCR}$, and CDCR, respectively.

\section{DISCUSSION}

Given the importance of colostrum management and feeding to calf's health and profitability (Robison et al., 1988; Fowler, 1999; Faber et al., 2005), it is imperative that producers are well informed of the benefits or detriments of feeding $\mathrm{MC}$ or different types of CR. First, our results did not corroborate with earlier observations (Quigley et al., 2002) that a lower cutoff for serum TP (i.e., 4.2 or $4.85 \mathrm{~g} / \mathrm{dL}$ ) should be used to determine adequate passive transfer when feeding a PDCR. The cutoffs ranged from $>5.1$ to $>5.6$, with PDCR having the highest cutoff at $>5.6 \mathrm{mg} / \mathrm{dL}$. These results support the long standing recommendation to use a cutoff between 5.2 and $5.5 \mathrm{~g} / \mathrm{dL}$ to determine adequate passive transfer (Donovan et al., 1998; Tyler et al., 1998; Weaver et al., 2000) regardless of type of colostrum. A recent study (Swan et al., 2007) observed that cutoffs were very similar for $\mathrm{MC}(5.1 \mathrm{mg} / \mathrm{dL})$ and PDCR $(5.0$

Table 3. Effect of treatment with different types of colostrum on mortality and morbidity from birth to weaning

\begin{tabular}{|c|c|c|c|c|c|c|c|}
\hline \multirow[b]{2}{*}{ Variable $^{1}$} & \multirow[b]{2}{*}{ Level $^{2}$} & \multirow[b]{2}{*}{$\begin{array}{c}\text { Affected, } \% \\
\text { (no./no.) }\end{array}$} & \multirow[b]{2}{*}{$\mathrm{OR}^{3}$} & \multirow[b]{2}{*}{$95 \%$ CI } & \multicolumn{3}{|c|}{$P$-value ${ }^{4}$} \\
\hline & & & & & TRT & $\mathrm{C} 1$ & $\mathrm{C} 2$ \\
\hline \multicolumn{8}{|l|}{ Morbidity } \\
\hline \multirow{3}{*}{ Treatment } & PDCR & $71.4(35 / 49)$ & 2.8 & $1.2-6.5$ & 0.01 & - & - \\
\hline & CDCR & $67.3(33 / 49)$ & 2.3 & $1.0-5.3$ & 0.04 & - & - \\
\hline & $\mathrm{CR}$ & $69.4(68 / 98)$ & 2.6 & $1.3-5.2$ & - & - & - \\
\hline \multirow{3}{*}{ Treatment } & PDCR & $16.3(8 / 49)$ & 2.2 & $0.6-7.8$ & 0.22 & - & - \\
\hline & CDCR & $24.5(12 / 49)$ & 3.7 & $1.1-12.3$ & 0.03 & - & - \\
\hline & $\mathrm{CR}$ & $20.4(20 / 98)$ & 2.9 & $0.9-9.0$ & - & - & - \\
\hline
\end{tabular}

\footnotetext{
${ }^{1}$ Morbidity was defined by occurrence of any disease event (pneumonia, diarrhea, septic arthritis, or omphalitis) from birth to weaning. Mortality was defined by occurrence of death because of a disease event.

${ }^{2} \mathrm{MC}=$ calves that were fed $3.8 \mathrm{~L}$ of maternal colostrum within $2 \mathrm{~h}$ of birth; PDCR $=$ calves that were fed $550 \mathrm{~g}$ of plasma-derived colostrum replacer (Acquire Colostrum Replacer, Ankeny, IA) containing $150 \mathrm{~g}$ of Ig dissolved in warm water $(\sim 3.4 \mathrm{~L})$ to make $3.8 \mathrm{~L}$ of solution within 2 $\mathrm{h}$ of birth; CDCR = calves that were fed $470 \mathrm{~g}$ of colostrum-derived colostrum replacer (Alta Calf's Choice Total Balanced; Alta Genetics USA Inc., Watertown, WI) containing $100 \mathrm{~g}$ of $\mathrm{Ig}$ dissolved in warm water $(\sim 3.45 \mathrm{~L})$ to make $3.8 \mathrm{~L}$ of solution within $2 \mathrm{~h}$ of birth; CR $=$ values for PDCR combined with CDCR.

${ }^{3} \mathrm{OR}=$ odds ratio.

${ }^{4} \mathrm{TRT}=$ treatment; $\mathrm{C} 1=$ contrast between $\mathrm{MC}$ and $\mathrm{CR}(\mathrm{PDCR}$ combined with CDCR); $2=$ contrast between PDCR and CDCR.
} 


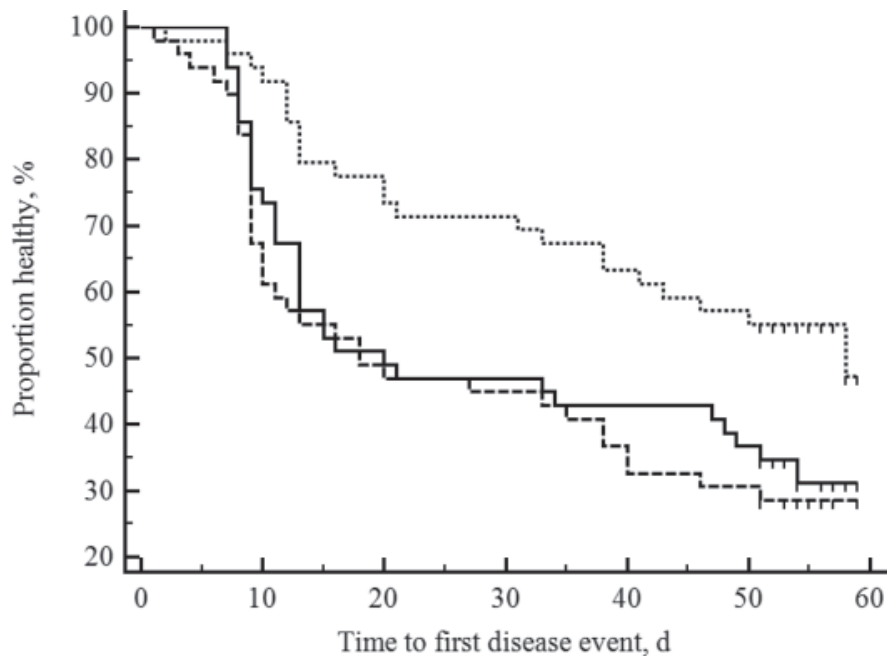

Figure 1. Time to first disease event for calves that within $2 \mathrm{~h}$ of birth were either fed $3.8 \mathrm{~L}$ of maternal colostrum ( $\mathrm{MC}$; $\mathrm{n}=49$; dotted line), $550 \mathrm{~g}$ of plasma-derived colostrum replacer (PDCR; Acquire Colostrum Replacer, Ankeny, IA) containing $150 \mathrm{~g}$ of Ig dissolved in warm water to make $3.8 \mathrm{~L}$ of solution $(\mathrm{n}=49$; dashed line), or $470 \mathrm{~g}$ of colostrum-derived colostrum replacer (CDCR; Alta Calf's Choice Total Balanced; Alta Genetics USA Inc., Watertown, WI) containing $100 \mathrm{~g}$ of Ig dissolved in warm water to make $3.8 \mathrm{~L}$ of solution $(\mathrm{n}=$ 49; solid line). An effect of treatment $(P=0.009)$ was observed, with MC having increased $(P<0.02)$ time to first disease event compared with PDCR and CDCR. Contrasts showed that MC had an increased time to first disease event $(P=0.003)$ compared with $\mathrm{CR}$ (PDCR combined with CDCR), but PDCR was not different than CDCR $(P$ $=0.54$ ). Median time to first disease event was 58, 18, and $20 \mathrm{~d}$ for MC, PDCR, and CDCR, respectively. Proportions of healthy calves were 53.1 (26/49), $28.6(14 / 49)$, and 32.7\% (16/49) for MC, PDCR, and CDCR, respectively.

$\mathrm{mg} / \mathrm{dL}$ ). One important distinction from previous studies is that ROC curve analysis was used to determine the cutoffs instead of estimating them based on a linear regression equation. Although a linear regression equation will estimate what TP value would correspond to a certain concentration of $\mathrm{IgG}$ (e.g., 1,000 mg/dL), that value is not based on the optimal sensitivity and specificity for the test. Zweig and Campbell (1993) stated that ROC plots provide a pure index of accuracy by determining the limits of a test's ability to discriminate between alternative states of health (i.e., adequate passive transfer) over the complete spectrum of operating conditions (i.e., concentration of serum TP). Although it has been suggested that a bovine PDCR may allow superior absorption compared to a lacteal-derived CR (Quigley et al., 2001), that was not observed in this study. In fact, AEA of IgG was higher for the CDCR than for PDCR, which corroborates observations made by others (Place et al., 2010). The AEA for CDCR is similar to previous reports (Godden et al., 2009a) with a different brand of CDCR (Land O'Lakes Colostrum Replacer; Land O'Lakes Inc., St. Paul, MN),

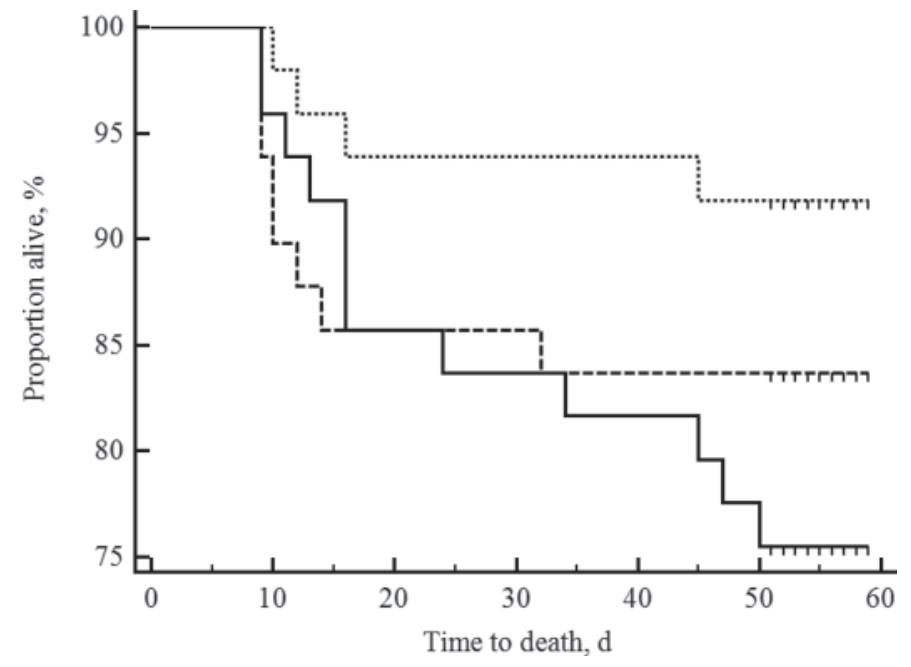

Figure 2. Time to death for calves that within $2 \mathrm{~h}$ of birth were either fed 3.8 L of maternal colostrum (MC; $\mathrm{n}=49$; dotted line), 550 $\mathrm{g}$ of plasma-derived colostrum replacer (PDCR; Acquire Colostrum Replacer, Ankeny, IA) containing $150 \mathrm{~g}$ of Ig dissolved in warm water to make $3.8 \mathrm{~L}$ of solution ( $\mathrm{n}=49$; dashed line), or $470 \mathrm{~g}$ of colostrum-derived colostrum replacer (CDCR; Alta Calf's Choice Total Balanced; Alta Genetics USA Inc., Watertown, WI) containing $100 \mathrm{~g}$ of $\mathrm{Ig}$ dissolved in warm water to make $3.8 \mathrm{~L}$ of solution $(\mathrm{n}=49$; solid line). A tendency $(P=0.10)$ for an effect of treatment was observed; MC treatment had an increased $(P=0.03)$ time to death compared with CDCR but was similar $(P=0.20)$ to PDCR. Contrasts showed that MC had a tendency for increased time to death $(P=0.06)$ compared with CR (PDCR combined with CDCR), but PDCR was not different than CDCR $(P=0.39)$. Median time to death was not calculated because more than $50 \%$ of the calves were alive at the end of the study. Proportions of live calves were 91.8 (45/49), 83.7 (41/49), and $75.5 \%(37 / 49)$ for MC, PDCR, and CDCR, respectively.

where AEA ranged from 35.5 to $36.5 \%$. The AEA for PDCR was lower than in some previous reports using a PDCR (Quigley et al., 2002) where AEA was 30\%. However, results were within values reported in others (Quigley et al., 2001) where AEA of a PDCR (APC Inc.) containing 100 to $122 \mathrm{~g}$ of IgG ranged from 19 to $32 \%$, or when the same PDCR used in this study was evaluated (Jones et al., 2004) where AEA was $20.3 \%$. The authors speculated that low AEA observed by Quigley et al. (2001) was either caused by a method of fractionating bovine plasma to concentrate $\operatorname{IgG}$ that utilized polyethylene glycol $(\mathrm{AEA}=19 \%)$ or feeding of $\mathrm{CR}$ twice, $8 \mathrm{~h}$ apart (AEA $=19-20 \%)$. In the study by Jones et al. (2004) calves were also fed twice, $12 \mathrm{~h}$ apart. It is not clear if polyethylene glycol is currently used for fractionation of bovine plasma to manufacture PDCR because APC Inc. could not disclose that information (Javier Polo, Vice President for Research and Development, APC Inc. personal communication). In the current study, both CR were fed once; therefore, twice feeding cannot explain the low AEA for PDCR. It is worth noting that the recommendations for feeding 
PDCR and CDCR are to dissolve the product in warm water to make a solution of 1.5 or $1.9 \mathrm{~L}$ for CDCR or PDCR, respectively. Hence, both products were dissolved into a higher quantity of solution $(3.8 \mathrm{~L})$; however, it is unclear whether this could affect one product differently than the other. Feeding method (i.e., bottle vs. esophageal tube) does affect IgG concentration and AEA when smaller volumes $(1.5 \mathrm{~L})$ are fed but not when larger volumes $(3.0 \mathrm{~L})$ are fed (Godden et al., 2009b). In the current study both CR groups were fed using an esophageal tube.

As expected, calves fed $3.8 \mathrm{~L}$ of good quality $\mathrm{MC}$ within $2 \mathrm{~h}$ of birth had greater IgG concentrations and a greater proportion of adequate passive transfer than calves fed one dose of CR (Foster et al., 2006; Godden et al., 2009a). Greater IgG concentration in calves fed $\mathrm{MC}$ is likely the result of feeding a higher amount of IgG ( $\geq 190 \mathrm{~g})$ compared with 1 dose of CR (100 or $150 \mathrm{~g})$. However, CDCR having a greater proportion of adequate passive transfer than PDCR was somewhat unexpected because of the higher $\operatorname{IgG}$ content of 1 dose of PDCR compared with 1 dose of CRCR. This highlights the importance of both the amount of $\operatorname{IgG}$ fed and the AEA. Previous studies have observed that as few as 7 (Swan et al., 2007) to $10 \%$ (Foster et al., 2006) of calves have adequate passive transfer when fed 1 dose (125 g of IgG) of PDCR (Acquire, APC Inc.) or 1 dose (100 g of IgG) of CDCR (Immu-Start 50, Immu-Tek Animal Health Inc., Fort Collins, CO), respectively. On the other hand, as many as $81 \%$ of calves had adequate passive transfer when fed 1 dose (100 g of IgG) of a CDCR (Land O'Lakes Colostrum Replacer; Foster et al., 2006). Although the proportion of CDCR-fed calves achieving adequate passive transfer was lower than what was observed by Foster et al. (2006), the mean IgG concentration was very similar $(1,160 \mathrm{mg} / \mathrm{dL})$. Nonetheless, serum concentration of IgG and proportion of adequate passive transfer similar to what is achieved when feeding $3.8 \mathrm{~L}$ of MC has only been demonstrated when feeding $200 \mathrm{~g}$ of CDCR (Foster et al., 2006; Godden et al., 2009a). When amount of $\mathrm{MC}$ fed was restricted $(1.42 \mathrm{~L}$ for Holsteins and 1.06 L for Jerseys) so that amount of IgG fed was similar to what was delivered with PDCR (250 g divided in 2 feedings $12 \mathrm{~h}$ apart), serum IgG concentration was also similar (Jones et al., 2004). Although Ig concentration was similar between $\mathrm{MC}$ and $\mathrm{CR}(\sim 1,400 \mathrm{mg} / \mathrm{dL})$, this feeding scheme still resulted in $31 \%$ failure of passive transfer in Holstein calves because IgG concentration in female and male Holsteins averaged 990 and 1,235 $\mathrm{mg} / \mathrm{dL}$, respectively. Therefore, further investigation is needed to evaluate if feeding a higher dose of PDCR can achieve similar serum IgG concentration and pro- portion of adequate passive transfer as feeding $3.8 \mathrm{~L}$ of good quality MC.

Effect of feeding CR on weaning weight and BW gain has been evaluated in very few studies (Quigley et al., 2001; Jones et al., 2004). Quigley et al. (2001) observed a tendency for MC-fed calves to gain more BW from birth to weaning at $60 \mathrm{~d}$ of age, but no difference was observed in weaning weight. Jones et al. (2004) observed higher feed efficiency for calves fed MC, and a tendency for MC-fed calves to gain more BW in the first week of life but not during the first $29 \mathrm{~d}$. Therefore, to our knowledge, this is the first time that lower weaning weight and BW gain has been reported when feeding 1 dose of $\mathrm{CR}$ compared with $3.8 \mathrm{~L}$ of MC. Failure to show a statistical difference might have arisen from lack of power or simply because of different experimental design. In the study by Quigley et al. (2001) the MC group only had 14 calves, and in the study by Jones et al., (2004) feeding of MC was restricted (1.42 L for Holsteins and $1.06 \mathrm{~L}$ for Jerseys) to match the IgG concentration in PDCR. Decreased weaning weight and BW gain from birth to weaning was likely a consequence of having inadequate IgG intake leading to increased morbidity in calves fed 1 dose of $\mathrm{CR}$, as calves that had at least 1 disease event had decreased BW at weaning and gained less BW from birth to weaning.

As with weaning weight and BW gain, only 2 reports from 1 experiment evaluated the effect of feeding 1 dose of CR on morbidity (Swan et al., 2007) and mortality (Swan et al., 2007; Pithua et al., 2010) of dairy calves. In those studies, 11 of the 12 farms fed $3.8 \mathrm{~L}$ of $\mathrm{MC}$, one farm fed $1.9 \mathrm{~L}$ of $\mathrm{MC}$ at first feeding, and 7 farms provided a second feeding of $1.9 \mathrm{~L}$ of MC 8 to $12 \mathrm{~h}$ after first feeding. Despite the fact that $93 \%$ of CR-fed calves had failure of passive transfer, and the known negative effect of failure of passive transfer on morbidity and mortality (Robison et al., 1988; Wells et al., 1996; Donovan et al., 1998), neither the study by Swan et al. (2007) or that of Pithua et al. (2010) found statistical differences in morbidity or mortality from birth to weaning (Swan et al., 2007) or mortality from birth to first calving (Pithua et al., 2010). Swan et al. (2007) alluded to poor MC quality or acceptable protection from 1 dose of $\mathrm{CR}$ as possible reasons for a lack of significant differences. Indeed, MC total plate count and total coliform count were $16.1 \times 10^{6}$ and $2.7 \times$ $10^{6} \mathrm{cfu} / \mathrm{mL}$, respectively. Furthermore, although most herds were fed $3.8 \mathrm{~L}$ of $\mathrm{MC}$, IgG concentration was lower $(1,480 \mathrm{mg} / \mathrm{dL})$ than what was observed in the current study, and $28 \%$ of calves had failure of passive transfer compared with only $8.2 \%$. In the current study, higher morbidity and mortality for calves fed 1 dose of CR is likely a result of greater failure of passive transfer 
given the observed higher morbidity and mortality for calves with failure of passive transfer. Nonetheless, the notion of acceptable protection from CR may only apply when comparing both CR, because although CDCR had greater proportion of calves with adequate passive transfer than PDCR, no difference was observed in morbidity or mortality. Calves fed CDCR did have a tendency to have higher weaning weight and higher BW gain from birth to weaning, but this may have been confounded by the fact that 4 more calves died in the CDCR group; therefore, further research is needed to evaluate weaning weight, weight gain, morbidity, and mortality between PDCR and CDCR. A need also exists to compare calf performance when amount of IgG from $\mathrm{CR}$ matches the amount in $3.8 \mathrm{~L}$ of $\mathrm{MC}$ (i.e., $\geq 190 \mathrm{~g})$.

\section{CONCLUSIONS}

Cutoffs for determining adequate passive transfer should be maintained between 5.2 and $5.5 \mathrm{~g} / \mathrm{dL}$ regardless of type of colostrum. The approach we take in our veterinary ambulatory clinic is to classify calves between 5.2 and $5.5 \mathrm{~g} / \mathrm{dL}$ as having partial passive transfer and calves above $5.5 \mathrm{~g} / \mathrm{dL}$ as having adequate passive transfer of immunity. Calves fed $3.8 \mathrm{~L}$ of good quality MC had increased IgG concentration, adequate passive transfer of immunity, weaning weights and $\mathrm{BW}$ gain, and decreased morbidity and mortality compared with calves fed 1 dose (100 or $150 \mathrm{~g}$ of IgG) of 2 commercially available CR. Calves fed CDCR had increased passive transfer of immunity and AEA compared with calves fed PDCR. Given the conditions of this trial, $\mathrm{MC}$ was superior to CR. Further research is needed to evaluate calf performance when a higher dose of $\mathrm{CR}$ is fed.

\section{ACKNOWLEDGMENTS}

The authors thank the owner of Dairy Production Systems, David P. Sumrall, and the managing staff, Michael and Arthur J. Pedreiro, for allowing the use of their animals for this experiment. Our thanks extend to Laura Neumann, for assisting with IgG assays, Art Donovan and Fiona Maunsel, for allowing the use of their scale, and APC Inc. (Ankeny, IA) and Alta Genetics USA Inc. (Watertown, WI) for providing CR for the trial.

\section{REFERENCES}

Bicalho, R. C., K. N. Galvão, C. L. Guard, and J. E. Santos. 2008. Optimizing the accuracy of detecting a functional corpus luteum in dairy cows. Theriogenology 70:199-207.
Chigerwe, M., J. W. Tyler, J. R. Middleton, J. N. Spain, J. S. Dill, and B. J. Steevens. 2008a. Comparison of four methods to assess colostral IgG concentration in dairy cows. J. Am. Vet. Med. Assoc. 233:761-766.

Chigerwe, M., J. W. Tyler, L. G. Schultz, J. R. Middleton, B. J. Steevens, and J. N. Spain. 2008b. Effect of colostrum administration by use of oroesophageal intubation on serum IgG concentrations in Holstein bull calves. Am. J. Vet. Res. 69:1158-1163.

Dawes, M. E., J. W. Tyler, D. Hostetler, J. Lakritz, and R. Tessman. 2002. Evaluation of a commercially available immunoassay for assessing adequacy of passive transfer in calves. J. Am. Vet. Med. Assoc. 220:791-793.

Donovan, G. A., I. R. Dohoo, D. M. Montgomery, and F. L. Bennett. 1998. Associations between passive immunity and morbidity and mortality in dairy heifers in Florida, USA. Prev. Vet. Med. 34:31-46.

Faber, S. N., N. E. Faber, T. C. McCauley, and R. L. Ax. 2005. Effects of colostrum ingestion on lactational performance. Prof. Anim. Sci. 21:420-425.

Fidler, A. P., M. L. Alley, and G. W. Smith. 2011. Short communication: Serum immunoglobulin $\mathrm{G}$ and total protein concentrations in dairy calves fed a colostrum-replacement product. J. Dairy Sci. 94:3609-3612.

Foster, D. M., G. W. Smith, T. R. Sanner, and G. V. Busso. 2006. Serum IgG and total protein concentrations in dairy calves fed two colostrum replacement products. J. Am. Vet. Med. Assoc. 229:1282-1285.

Fowler, M. A. 1999. What is it worth to know a calf's IgG level? In Proc. Annu. Prof. Dairy Heifer Growers Assoc. Conf., Savoy, IL, 3:31-38. Prof. Dairy Heifer Growers Assoc., Savoy, IL.

Godden, S. M., D. M. Haines, and D. Hagman. 2009a. Improving passive transfer of immunoglobulins in calves. I: Dose effect of feeding a commercial colostrum replacer. J. Dairy Sci. 92:1750-1757.

Godden, S. M., D. M. Haines, K. Konkol, and J. Peterson. 2009b. Improving passive transfer of immunoglobulins in calves. II: Interaction between feeding method and volume of colostrum fed. J. Dairy Sci. 92:1758-1764.

Hull, V. J. 1980. Intermediate variables in the explanation of differential fertility: Results of a village study in rural Java. Hum. Ecol. 8:213-243.

Jones, C. M., R. E. James, J. D. Quigley III, and M. L. McGilliard. 2004. Influence of pooled colostrum or colostrum replacement on IgG and evaluation of animal plasma in milk replacer. J. Dairy Sci. $87: 1806-1814$.

McGuirk, S. M., and M. Collins. 2004. Managing the production, storage, and delivery of colostrum. Vet. Clin. North Am. Food Anim. Pract. 20:593-603.

Mowrey, C. M. 2001. Influence of feeding pooled colostrum or colostrum replacement on IgG levels and evaluation of animal plasma as a milk replacer protein source. MS Thesis. Virginia Tech, Blacksburg.

Pithua, P., S. M. Godden, J. Fetrow, and S. J. Wells. 2010. Effect of a plasma-derived colostrum replacement feeding program on adult performance and longevity in Holstein cows. J. Am. Vet. Med. Assoc. 236:1230-1237.

Pithua, P., S. M. Godden, S. J. Wells, and M. J. Oakes. 2009. Efficacy of feeding plasma-derived commercial colostrum replacer for the prevention of transmission of Mycobacterium avium subsp paratuberculosis in Holstein calves. J. Am. Vet. Med. Assoc. 234:11671176 .

Place, N., A. Bents, K. Leslie, B. Nelson, D. Haines, and S. Godden. 2010. Relationship between serum total protein and serum IgG in Holstein calves fed either a lacteal- or plasma-derived colostrum replacer. Proc. Ann. Conf. AABP, Albuquerque, NM. 43:193. Am. Assoc. Bovine Pract., Auburn, AL

Poulsen, K. P., A. L. Foley, M. T. Collins, and S. M. McGuirk. 2010. Comparison of passive transfer of immunity in neonatal dairy calves fed colostrum or bovine serum-based colostrum replacement and colostrum supplement products. J. Am. Vet. Med. Assoc. 237:949-954. 
Quigley, J. D., III, and J. J. Drewry. 1998. Nutrient and immunity transfer from cow to calf pre- and postcalving. J. Dairy Sci. 81:2779-2790.

Quigley, J. D., III, C. J. Kost, and T. M. Wolfe. 2002. Absorption of protein and IgG in calves fed a colostrum supplement or replacer. J. Dairy Sci. 85:1243-1248.

Quigley, J. D., III, R. E. Strohbehn, C. J. Kost, and M. M. O'Brien. 2001. Formulation of colostrum supplements, colostrum replacers and acquisition of passive immunity in neonatal calves. J. Dairy Sci. 84:2059-2065.

Robison, J. D., G. H. Stott, and S. K. DeNise. 1988. Effects of passive immunity on growth and survival in the dairy heifer. J. Dairy Sci. $71: 1283-1287$.

Stott, G. H., and A. Fellah. 1983. Colostral immunoglobulin absorption linearly related to concentration for calves. J. Dairy Sci. 66:1319-1328

Swan, H., S. Godden, R. Bey, S. Wells, J. Fetrow, and H. ChesterJones. 2007. Passive transfer of immunoglobulin G and preweaning health in Holstein calves fed a commercial colostrum replacer. J. Dairy Sci. 90:3857-3866.
Tao, S., A. P. Monteiro, I. M. Thompson, M. J. Hayen, and G. E. Dahl. 2012. Effect of late-gestation maternal heat stress on growth and immune function of dairy calves. J. Dairy Sci. 95:7128-7136. http://dx.doi.org/10.3168/jds.2012-5697.

Tyler, J. W., D. D. Hancock, S. E. Wiksie, S. L. Holler, J. M. Gay, and C. C. Gay. 1998. Use of serum protein concentration to predict mortality in mixed-source dairy replacement heifers. J. Vet. Intern. Med. 12:79-83.

Weaver, D. M., J. W. Tyler, D. C. VanMetre, D. E. Hostetler, and G. M. Barrington. 2000. Passive transfer of colostral immunoglobulins in calves. J. Vet. Intern. Med. 14:569-577.

Wells, S. J., D. A. Dargatz, and S. L. Ott. 1996. Factors associated with mortality to 21 days of life in dairy herds in the United States. Prev. Vet. Med. 29:9-19.

Zweig, M. H., and G. Campbell. 1993. Receiver-operating characteristic (ROC) plots: A fundamental evaluation tool in clinical medicine. Clin. Chem. 39:561-577. 